\title{
THE APPEARANCE OF THE HIPPOCENTAUR IN THE HERALDRY OF THE NOBILITY OF THE GRAND DUCHY OF LITHUANIA
}

\author{
Agnè Railaité-Bardé
}

\begin{abstract}
The Centaur or Hippocentaur in the heraldry of the nobility of the Grand Duchy of Lithuania has been little investigated. This theme is a not yet fully exhausted granary of heraldic studies, which, due to the lack of primary sources, raises more questions than it has answers for scholars. The question of where and in what way the Centaur, which later turned into a Hippocentaur, appeared in the heraldry of the nobility of the GDL remains a blank spot in historiography. This article discusses the history and symbolism of centaurs, analyses the Centaur family described in Lithuania's chronicles, investigates the assumptions for the selection of the Alšeniškis coat of arms, the transformation of the Centaur to the Hippocentaur, and the appearance of the Hippocentaur coat of arms in the heraldry of the Giedraitis in the 16th century. The concepts of the Centaur, Hippocentaur, Kitauras and archer (Sagittarius) are revised.
\end{abstract}

\section{Introduction}

Historiography The Centaur, or Hippocentaur, in the heraldry of the nobility of the GDL has been investigated, but rarely. This theme is a not yet fully exhausted aspect of heraldic studies, which, due to the lack of primary sources, raises more questions than it has answers for scholars. Typically, this coat of arms is mentioned during research on the coats of arms of the nobles, or in analysing the peripeteia of the theory of the Lithuanians' origin in the Romans. Overall, the coats of arms of the nobility of the GDL have been investigated very little in historiography. Probably, the coat of arms of the Bishop of Vilnius Paulius Alšèniškis has received the most attention from researchers, although one should keep in mind that the analysis of the coat of arms of this dignitary is often not the main object of the work, but only an additional excursion in her- 
aldry along with other analysed issues. Apart from episodic works by Józef Puzyna ${ }^{1}$ and Helena Polaczkówna ${ }^{2}$, the most detailed study of a coat of arms is the work of Marceli Antoniewicz, on the coat of arms of Paulius Alšèniškis, in which, according to the author, the first two fields in the bishop's coat of arms depicted the coats of arms of the male line, without doubt showing the ducal origin of Paulius Alšèniškis, while the third and fourth, less important, were left to the female line, which was not distinguished by princely titles, or coats of arms ${ }^{3}$. This coat of arms is interesting in that in the first field there is the Hippocentaur coat of arms, inherited from his father. The coat of arms of a contemporary Bishop of Vilnius Chancellor Albertas Goštautas of the GDL, in whose second field is the Hippocentaur coat of arms, has also attracted the attention of researchers ${ }^{4}$. In one of these works, all the attention was devoted to the coat of arms of this dignitary as a key in helping to resolve the existing confusion in historiography on the lineage and heraldry of Albertas Goštautas ${ }^{5}$. Oleg Odnorozhenko, exploring the heraldry of dukes, presents chronologically the seals and heraldry sources of the Alšèniškis dukes that used the Hippocentaur coat of arms, from the founder of the family, Jonas Algimantaitis, but does not undertake to decide what was the genesis of the coat of arms of these dukes ${ }^{6}$. Jan Jurkiewicz' study, 'Palemon, Kolumny i Centaury. Kilka uwag o bohaterach legendy o rzymskim pochodzeniu Litwinów', is probably the first swallow in research in this area. The scholar discusses the

1 J. Puzyna, 'Herb złożony Pawła Holszańskiego, biskupa wileńskiego', Miesięcznik heraldyczny, 6 (1932), Nr. 6, pp. 10-12.

${ }^{2}$ H. Polaczkówna, 'Przećwiertowana tarcza Pawła Algimunta Holszańskiego', Stemmata Polonica. Rękopis 1114 klejnotów Dlugosza $w$ bibliotece Arsenatu $w$ Paryżu (Lwów, 1926), pp. 84-86.

${ }^{3}$ M. Antoniewicz, 'Manifestacja genealogiczna w herbie złożonym biskupa Pawła Olgimunta księcia Hołszańskiego', Zeszyty Historyczne (1997), z. 4, pp. 387-434.

${ }^{4}$ W. Zahorski, Katedra Wileńska (Vilnius, 1904); S. Cercha, 'Pomnik Wojciecha Gasztolda w Katedrze Wileńskiej’, Kwartalnik Litewsk, rok I, t. 1 (1910), pp. 34-40; A. Širmulis, 'Seniausias profesionaliosios antkapinès skulptūros paminklas Lietuvoje', Nuo gotikos iki romantizmo. Senoji Lietuvos daile (Vilnius, 1992), pp. 30-43.

${ }^{5}$ A. Railaitè, 'Kodèl Alberto Goštauto jungtiniame herbe nèra dvigalvio erelio?', Jaunuju mokslininku darbai (2007), nr. 3(14), pp. 13-21.

${ }^{6}$ O. Odnorozhenko, Kniazivs'ka geral'dika Volinii seredini XIV-XVIII st. (Kharkhiv, 2008), pp. 164-77. 
genesis of the Centaur in Alšèniškïs heraldry, from aspects of Greek mythology and the influence of ancient Russian culture ${ }^{7}$.

Not many of the nobility of the GDL used the Hippocentaur or Centaur coat of arms. They are the Alšèniškis, Giedraitis, Hornostajas, Daumantas-Siesickis and Svirskis families. The coat of arms can be found in the coats of arms of other nobles of the GDL, for example, the coat of arms of members of the Palubinskas family ${ }^{8}$. In the seal of Povilas Pacas ${ }^{9}$ are the coats of arms of these individuals. Probably the most closely tied to the theory of Roman origins are the Alšèniškis and Giedraitis families, whose origins in the Romans are already mentioned in Lithuanian chronicles from the 16th century.

The Centaur is closely related to the theory of the Lithuanian origin in the Romans, because in historiography the provision was formed and developed that Palemonas came to Lithuania together with several of his comrades, one of whom, Dausprungas, having become the founder of more than one family of nobles, used the Centaur coat of arms. In the 16th century, as Renaissance ideas spread and became established, the Hippocentaur coat of arms became a mark of prestige, showing the age and integrity of its holders' family.

Nevertheless, the question from where and in what way the Centaur, which later turned into the Hippocentaur, appeared in the heraldry of the nobility of the GDL, remains a blank spot in historiography. This article will discuss the history and symbolism of centaurs, analyse the Centaur family described in Lithuanian chronicles, and investigate the choice of the Alšeniškis coat of arms, the transformation of the Centaur to the Hippocentaur, and the assumptions for the appearance of the Hippocentaur in the heraldry of the Giedraitis in the 16th century.

The concept problem In historiography, there is a problem about the name of the analysed coat of arms. There is no clear dividing line drawn between the Centaur and the Hippocentaur. Often researchers confuse the names of these two different coats of arms.

7 J. Jurkiewicz, 'Palemon, Kolumny i Centaury. Kilka uwag o bohaterach legendy o rzymskim pochodzeniu Litwinów', Studia z historii społecznej (Białystok, 2004), p. 140.

${ }^{8}$ Drzewo genealogiczne rodu Połubińskich, 1675, Warsaw, Biblioteka Narodowa, G. 2165; Warsaw, Archiwum Główne Akt Dawnych (AGAD), Zbiór Dokumentów Papierowych, Nr. 2838.

${ }^{9}$ Seal of Povilas Pacas in 1589 m., AGAD, Archiwóm Radziwiłłów (onward $A R)$, dz. 10 , sygn. $16,1.31$. 
In historiography, the Centaur is most commonly used. On the other hand, the Hippocentaur is more characteristic of Polish historiography, although Albertas Vijūkas-Kojalavičius was probably the first to introduce the concept of the Hippocentaur into historiography ${ }^{10}$. The Centaur should be called a mythical fantastic creature, with the form of a man from the waist up, and of a horse below. The Hippocentaur is the consequence of the centaur of antiquity and the influence of the Catholic faith in Western Europe. The Hippocentaur differs from the centaur in that its tail has turned into a grass snake, into whose jaws an arrow is released from a bow. Nevertheless, in some 17 th century armorials, the Hippocentaur was also portrayed as an ordinary centaur ${ }^{11}$, but for the sake of accuracy, we think that in the future there should be a clear dividing line between the two names. Another fantastic creature, about which there will be some discussion later, is the Kitauras, a young winged centaur ${ }^{12}$. In foreign literature, especially in Western Europe, the Centaur is also known as the Archer (Sagittarius), and is usually associated with astrology.

\section{History and symbolism of centaurs}

The emergence of the half man-half horse creature in the world outlook of people is usually associated with the collision of early cultures still ignorant about riding with attacking mounted riders. The man and horse might have appeared to them as a single totality ${ }^{13}$. According to one version of the origin of centaurs, the genesis of these supernatural creatures is associated with the Thracians and Thessalians, who hunted bulls on horseback ${ }^{14}$. According to another assumption, centaurs probably originated in Babylon, around $1750 \mathrm{BC}$, when the Kassites moved to Mesopotamia. The

${ }^{10}$ W. Kojałowicz-Wiiuk, Herbarz szlachhty Wielkiego Księstwa Litewskiego znany Nomenclator (Kraków, 1905), p. 182.

${ }^{11}$ Сборник, заключающій въ себе гербовникъ польскихъ фамилій и „Сопstitutiones regni Serenissimae eloquentiae reginae, animorum, collectae, atque in Radviliano Athaeneo collegii Nesvisiensis Soc. Iesu eloquentiae auditoribus traditae anno 1696.", LMAVB RS, F. 17-213, 1. 62.

12 V.V. Pokhlebkin, Slovar' mezhdynarodnoi simboliki i emblematiki (Moscow, 2004), pp. 461, 463.

${ }^{13}$ E. Atwood Lawrence, 'The Centaur: Its History and Meaning in Human Culture', The Journal of Popular Culture (Michigan, 1994), Vol. 27, Issue 4, pp. 57-58.

14 J. Vinycomb, Fictitious Symbolic Creatures in Art with Special Reference to Their Use in British Heraldry (London, 1906), p. 143. 
Kassites marked the boundaries of their lands using stone landmarks engraved with supernatural figures, among which were pictures of a half human-half horse. They differ from our usual centaurs in that these fantasy creatures had wings and the tail of a scorpion ${ }^{15}$. They were portrayed as hunters with bows. These are the firstknown images of centaurs/archers. Nevertheless, it is believed that perhaps centaurs appeared even earlier in India. It is assumed that the Hittites spread the image of the centaur in Greece, where this supernatural creature became popular and occupied a special place in the spiritual and artistic life of the ancient society ${ }^{16}$.

The first-known images of centaurs in the current territory of Russia are found in the late 12th and early 13 th centuries on the walls of the Dmitri and George cathedrals in Vladimir and Yur'ev. The centaur of the George Cathedral is depicted with a stick and a hare. A 12th-century image of the centaur is also in bone plate found in Pskov. Here, the centaur is depicted with a stick and a shield, and over his head there is a hydra curled into a knot. According to I.K. Labutina and O.A. Kondratyeva, this image of a centaur is just one of the few images of this fantasy creature in the Novgorod area in the 12th century. In a Romanesque-style chess piece of the same age found in the Padnepr region, the centaur is pictured holding a stick in his left hand and a caduceus in his right hand. It is interesting that a 14th-century Persian illustration shows a winged centaur, holding a stick in his left hand, ending in a star, while his tail is depicted as a curled Hydra biting the back of a centaur. This is an allusion to the myth of Hercules, when Hercules, rescuing his wife, kills the centaur Nessus with an arrow poisoned with the blood/bile of a hydra. An image which depicts a centaur and a hydra together is found in a 14th-century Russian psalter. In the Vasilii Gates of the early 14th-century Sophia Cathedral, one can see a composition of a hippocentaur with Solomon. Images of centaurs are visible in the stamps and coins of 12th to 14th-century nobles of Tver, Dmitrov and Novgorod ${ }^{17}$.

Probably centaurs are best known from the Ancient Greek myth about the battle between the Lapiths and centaurs that broke out

${ }^{15}$ R. Bagdasarov, 'Symbolics of the Constellations of Sagittarius and Centaurus in Russian Traditional Culture', Astronomical and Astrophysical Transactions, 20 (2001), pp. 975-976.

${ }^{16}$ Atwood Lawrence, 'The Centaur', pp. 57-58.

${ }^{17}$ Bagdasarov, 'Symbolics of the Constellations', pp. 981-985, 988-989. 
at the wedding of the Lapith leader Pirithous and Hippodamia ${ }^{18}$. Myths from antiquity provide a certain symbolism for the centaur. In Greek mythology, the centaur embodies the unbridled, wild force of nature, contrary to the social norms of society, and gaucherie, debauchery and drunkenness ${ }^{19}$. Negative characteristics were generally attributed to centaurs, apart from some exceptional creatures of this kind, associated with knowledge of the healing arts: 'Symbolically, they are the incarnation of bestiality, the coarse forces of nature and uncontrollable instincts as man's origin only partially tames their wild nature. In Physiologus, a work from late antiquity, the centaur is a symbol of a heretic, familiar with Christian doctrine, but using it the wrong way' ${ }^{20}$. Chiron, the only good centaur, had excellent knowledge of music, riding, the art of war, hunting and healing, unlike other centaurs usually depicted with a bow and arrow. It is interesting that namely the image of the Centaur, the archer, was adopted specifically in Christian symbolism, but for the early Christians, it meant uncontrolled passion, the devil ${ }^{21}$. While in Christian symbolism, centaurs are usually assigned negative values, nevertheless, St Clement of Alexandria (ca. 150-215) was able to discern a positive sense in them, claiming that man is similar to the centaur, which consists of intelligent and unwise parts, the heart and the body. The body is in the power of the earth, while the heart, if it is exercised with true philosophy, is directed to God ${ }^{22}$. Beryl Rowland claimed that the Centaur could even symbolise Christ as the archer, fighting against evil. In this way, the Centaur expresses many dichotomies: animal-man, wild-civilised, physical strengthintellect, passion-the mind, and so on ${ }^{23}$.

In Great Britain, distinguished nobles had the Sagittarius coat of arms on the battlefield ${ }^{24}$. In A. C. Fox-Davies' book A Complete Guide to Heraldry, it is noted that even though in heraldry the Centaur was used more often in continental Europe, in the heraldry of the English nobility this symbol was also often used. According to him,

${ }^{18}$ N. Kunas, Senovès Graikijos legendos ir mitai (Vilnius, 2003), pp. 252-254.

${ }^{19}$ D. Forstner, Świat symboliki chrześcijańskiej (Warsaw, 1990), p. 342; Atwood Lawrence, 'The Centaur', p. 59.

${ }^{20}$ H. Biedermann, Naujasis simboliu žodynas (Vilnius, 2002), pp. 192-193.

${ }^{21}$ Atwood Lawrence, 'The Centaur', pp. 59, 65.

${ }^{22}$ Forstner, Świat, p. 342.

${ }^{23}$ Atwood Lawrence, 'The Centaur', pp. 61-62, 66.

24 Vinycomb, Fictitious symbols, p. 141. 
the Lambert and Fletcher families had the Centaur. This mythical creature, as a shield holder, is found in the heraldry of Lord Hood of Avelon ${ }^{25}$. In the middle of the 15th century Nicholas Upton, in his work „De Studio Militari“", attributed three Centaurs/Sagittarii to the coat of arms used by King Stephen (1135-1154), the grandson of William the Conqueror. It is believed that the Centaur/Sagittarius coat of arms was assigned to the king because Stephen was crowned king of England in 1135 during the zodiac time of Sagittarius, or marking the victory of the king's archers ${ }^{26}$. However, there are no 12th-century written sources confirming that King Stephen used this particular coat of arms. All the attempts to assign to this king the Centaur/Sagittarius coat of arms are quite late, so that it would not be fitting to rely on them as sources confirming an undisputed fact.

\section{The Centaur in Lithuanian chronicles}

In 16th and 17th-century historiography of the GDL, the provision was established that the Alšèniškis and Giedraitis families were descended from Dausprungas, the comrade of the legendary Palemonas. This Roman theory of the origin of the Alšeniškis and Giedraitis dukes was formulated in Lithuanian chronicles in the first half of the 16th century. Later, Motiejus Stryjkovskis and Albert VijūkasKojalavičius repeated it $^{27}$.

25 A.C. Fox-Davies, A Complete Guide to Heraldry (New York, 2007), pp. 228-229.

${ }^{26}$ T. Woodcock, J.M. Robinson, The Oxford Guide to Heraldry (Oxford, 1988), illustration 35. In this book it is noted that Nicholas Upton's De Studio Militari was written about 1400 , but this most likely is a typographical error, since it is believed that N. Upton wrote this work about 1440.

27 Examples of current historiography on this topic: K. Avižonis, Rinktiniai raštai, t. 3 (Rome, 1982), pp. 245-273; J. Suchocki, 'Geneza litewskiej etnogenetycznej', Zapiski historyczne, 52 (1987), pp. 43-44; S.C. Rowell, 'Amžinos pretenzijos arba kaip turime skaityti elitinę literatūrą?', Seminarai (Vilnius, 1998), pp. 7-30; E. Raila, 'Lietuvos atradimas, arba Palemono prolegomenai', Naujasis židinys-Aidai, Nr. 4, 1995, pp. 298-303; A. Vasiliauskas, 'Antika ir Sarmatizmas', Lietuvos Didžiosios Kunigaikštijos kultūra (Vilnius, 2001), pp. 13-31; K. Gudmantas, 'Lietuvių kilmès iš romènų teorijos genezė ir ankstyvosios Lietuvos vardo etimologijos', Senoji Lietuvos literatūra, 17 (2004), pp. 245-268; R. Petrauskas, 'Socialiniai ir istoriografiniai lietuvių kilmès iš romėnų teorijos aspektai', ibid., pp. 270-284; K. Gudmantas, 'Vèlyvųjų Lietuvos metraščių veikejjai ir jų prototipai: „romènai“", Senoji Lietuvos literatūra, 18 (2004), pp. 113-138; M. Niendorf, Das Grössfurstentum Litauen. Studien zur Nationsbildung in der Frühen Neuzeit (1569-1795) (Wiesbaden, 2010), pp. 58-63; E. Gudavičius, 'Palemono sumanymo klausimas', Lietuvos istorijos studijos, 30 (2012), pp. 9-24. 
In the Lithuanian Chronicle it is written that the members of the Alšeniškis and Giedraitis family are offspring of the legendary prince Palemonas arriving in Lithuania from Rome. In the Bychowiec Chronicle, it is written that, fleeing from the rage of Attila's army, from Rome withdrew 'a prince, named Apollo [...] and with him five hundred Roman patricians. Among them were four Roman patrician families: Dausprungas of the Centaur coat of arms, Prosper Cezarin of the Pillar coat of arms, Julian of the Bear coat of arms, and Hector of the Rose coat of arms' ${ }^{28}$. Using the text of the Bychowiec Chronicles (the story starts with the times of Attila), it is possible to trace the line of the descendants of the legendary Palemonas ${ }^{29}$. From it, one can see that Alšys and Giedrys, 11th-generation descendants of the Palemonas family, were the founders of the Alšèniškis and Giedraitis families. This genealogy of the Palemonas family holds many uncertainties, because Alšys and Giedrys, according to the agnatine line, are the great-great-grandsons of Grand Duke Utenis' of Lithuania and Samogitia (after the death of Vykintas) son Šventaragis from the Centaur family. This is the first mention of a person using the Centaur coat of arms speaking about the Palemonas genealogy. In this way, bearing in mind the heraldry provided in the Bychowiec Chronicle, one can see that the Alšeniškis and Giedraitis dukes are descendants of Palemonas' comrade Dausprungas, who used the Centaur coat of arms. Unfortunately, this chronicle does not have a consistent account of the Dausprungas offspring, since more attention is paid to the Palemonas family.

In the legendary part of the Lithuanian chronicles, after the murder of Vaišvilkas, the son of the Lithuanian ruler Mindaugas, a descendant of Palemonas, there is a mention of the son of Utenis, Šventaragis, who, after becoming a duke of Lithuania, raised his family status, because his family once again became the ruling family (the so-called Centaur family replaced the deceased family of the Roman prince Palemonas $)^{30}$. It appears that the dukes Alšèniškis and Giedraitis, as Šventaragis' descendants, are not identified only with Palemonas' kin. This reveals that the Alšeniškis and Giedraitis dukes, as descendants of Šventaragis, are identified not only with the Palemonas family.

${ }^{28}$ Lietuvos metraštis: Bychovco kronika, vertè, ịvadą ir paaiškinimus parašè R. Jasas (Vilnius, 1971), p. 42.

${ }^{29}$ Ibid., pp. 41-66.

${ }^{30}$ Ibid., p. 59. 
This dual origin of the Alšenišskis and Giedraitis dukes can be explained by the middle collection of the Lithuanian Chronicles, in which, despite its legendary character, facts and the genealogy of Palemonas are set out more clearly in its text.

Comparing the Bychowiec Chronicle with the middle collection of the Lithuanian Chronicles (the story starts from the time of Nero), it can be said that the two texts up to the start of the rule of the Gediminid dynasty are nearly identical, but analysing the chronicles from a genealogical point of view, significant differences are noticed. From the genealogical line of the Palemonas family, recorded in the middle collection of the Lithuanian Chronicles, one can see that the grandson of Palemonas, Grand Duke Kernius, had a daughter called Pajauta, but no male offspring. In this way, he gave his daughter in marriage to the son of Dausprungas, who used the Centaur coat of arms, Kira (Gira?), who after the death of Kernius became his successor:

'И будучы он у старости своеи и не хотечы панства своего от дочки своее отдалити, и прынял до неи и ${ }^{\mathrm{M}}$ зятем своим его вчынил собе с Китавруса именемъ своим Кируса, сына Довпрункгова [...], и сам умер. А по нем начне княжыти на земли Литовскои тот зять его с Китаврус Кгирус'31.

This citation from the chronicle explains how the Palemonas family is linked to the Dausprungas family by matrimonial relations. The son of Pajauta, Kukovaitis, according to the chronicler, was the son of the Lithuanian and Žemaitijan (after the death of Vykintas) Grand Duke Živinbudas. The chronicler does not mention who the father of Živinbudas was, but it is noted that he was from the Centaur family ${ }^{32}$. Hence, Živinbudas was from the Dausprungas family (perhaps even the son of Dausprungas), and the second husband of Pajauta. Thus, it follows that the Alšèniškis and Giedraitis dukes by the agnatine line are descended from the legendary Dausprungas, but Pajauta is the link that might allow the Alšeniškis and Giedraitis also to be descended from the Roman prince Palemonas.

Motiejus Stryjkovskis in his works also mentions Palemonas as the forerunner of the Grand Dukes of Lithuania, who came with his comrades from Italy. The author even states that Palemonas used the Pillar coat of arms, unlike what was written in the Lithuanian chronicles Stryjkovskis notes that Živinbudas, after the death of his

31 Polnoe sobranie russkikh letopisei, t. 35: Letopisi belorussko-litovskie. Letopis' Rachinskogo, ed. N.N. Ulashchik (Moscow, 1980), p. 146.

32 Ibid., p. 146. 
wife's father, joined the Centaur with the Pillars, and used both of these coats of arms ${ }^{33}$.

Albertas Vijūkas-Kojalavičius also extends the existence of the theory of the Roman origin of the Alšeniškis and Giedraitis families. According to the latter, the Giedraitis coat of arms, the Hippocentaur, used by them until they quarrelled with the Alšeniškis family, is from Italy, arriving in Lithuania with Julianas Dausprungas, a distant ancestor of the Giedraitis. From this, one can see that Kojalavičius supports the reality of the Roman origin of the Giedraitis, but the genealogical information in his treatise differs somewhat from that found in the chronicles, because Kojalavičius considers Živinbudas to be the grandson and not the son of Dausprungas. Moreover, in the genealogy of the Dausprungas family, there is no Skirmantas, son of Šventaragis, mentioned in the Lithuanian chronicles. In his place Germantas is mentioned, along with two brothers, Trobis and Giliginas, one of whose five sons, Giedrius, was thought to be the pioneer of the Giedraitis ${ }^{34}$.

\section{The first centaur on seals of the Alšėniškiai (Holszański) dukes}

According to the available sources, it can be said that the centaur appears for the first time in the GDL on the seals of Simonas Jonaitis Alšèniškis and Mykolas Jonaitis Alšèniškis affixed to the Treaty of Melno of $1422 / 1423^{35}$. In the seal of Mykolas Jonaitis Alšèniškis, with vegetative ornaments reminiscent of the cross, a Centaur is depicted running to the heraldic left, and in his bent right hand over the shoulder behind his head he has lifted up a sword, while in his left he is holding a shield, similar to that of Lithuanian Grand Duke Kęstutis, usually called a Baltic shield in historiography. Below the centaur one can see a mark created from strokes so far unidentified. The seal of Simonas Jonaitis Alšèniškis has survived in much worse condition. Nevertheless, one can say

\footnotetext{
${ }^{33}$ M. Stryjkowski, O początkach, wywodach, dzielnościach, sprawach rycerskich $i$ domowych sławnego narodu litewskiego, żemojdzkiego i ruskiego, przedtym nigdy od żadnego ani kuszone, ani opisane, z natchnienie Bożego a uprzejmie pilnego doświadczenia (Warsaw, 1978), pp. 35, 155.

34 W. Kojałowicz Wijuk, Herbarz Rycerstwa W. X. Litewskiego tak zwany Compendium [reprint opracowania] (Poznań, 2002), pp. 4-7.

${ }^{35}$ P. Nowak, P. Pokora, Dokumenty strony polsko-litewskiej pokoju Metneńskiego z 1422 roku (Poznań, 2004), pp. 78-79.
} 
immediately that the composition of a Centaur also running to the heraldic left in his seal is different. This Centaur does not have a sword or a Baltic shield. Due to the poorer clarity of the seal, it is difficult to say exactly what he is holding in his bent raised hands. There is a chance that in his right hand he is holding a rod, ending with a sphere, and in his left hand a garden snake or a bow. These attributes are characteristic of two of the three centaurs depicted on the bronze doors of Gniezno Cathedral. Speaking about the early heraldry of the Alšeniškis, in the seal of Jonas Algimantaitis Alšeniškis, the father of Simonas Jonaitis and Mykolas Jonaitis Alšèniškis, mentioned in $1390^{36}$, there is a Byzantine-style figure of St John ${ }^{37}$. What circumstances led Simonas and Mykolas Jonaitis Alšeniškis to choose a completely different symbol to that of their father? A no less interesting question arises as to why the Centaur was chosen, usually expressing negative meanings. We will try to look at these questions by analysing the aspects of warfare and the Church.

It is difficult now to say for what reason the Alšeniškis princes chose the Centaur coat of arms. Not having exact sources pointing out the reason or reasons for the choice, one can lay out a possible mosaic of assumptions from the available material fragments. We believe that the choice of the centaur as his emblem could have been determined by warfare and Church issues. Bearing in mind that the Centaur appeared on the seals of the Alšeniškis GDL nobles in 1422/1423, while their father used the image of St John in his seal, it can assumed that the Centaur in Alšeniškis heraldry could have appeared at the turn of the 14th and 15th centuries, but no later than the first two decades of the 15th century. This period in the GDL's history is marked by intense wars with the Teutonic Order. The threat of frequent military conflicts must have influenced significantly the thinking of the nobles, and the desire to express a militant fighter spirit in their coat of arms. To that end, the centaur was a perfect fit: aggressive, symbolising both the rational mind and savagery. The perceptions of knighthood taken from Western countries, and the spread of its manifestations in the society of the GDL's nobles, might also have contributed to the reason for

${ }^{36}$ Codex epistolaris Vitoldi Magni Ducis Lithuaniae, 1376-1430, ed. A. Prochaska (Cracow, 1882), pp. 20-21.

${ }^{37}$ Based on consultations with doc. dr E. Rimša. 
the choice of the coat of $\operatorname{arms}^{38}$. One should also keep in mind the method of depicting centaurs in the analysed seals. This can be seen very well in the seal of Mykolas Jonaitis Alšèniškis, in which the Centaur is depicted with military trappings, i.e. a sword and a shield, running, prepared to fight. One should not forget that Simonas Jonaitis Alšèniškis, in 1420, on the instructions of Grand Duke Vytautas, had gone to Novgorod the Great, where, due to his strong rule, he was nicknamed 'the Merciless' ${ }^{39}$.

The centaur, together with lions, vultures, mermaids, two-tailed newts and other fantastic creatures, was an especially prevalent image in medieval ecclesiastical symbolism. One can find quite a few images of centaurs surviving to the present times in the interior and exterior architectural details of churches. The range of their spread is very wide: from northwest to southern Europe. Typically, these mythical beings are depicted in the portals, timpani and archivolts of facades, and less often in the columns of capitella. The bronze doors in the facades of churches built in the medieval period, having features of the Ottonian, Romanesque, and Byzantine styles, in which the centaur is often portrayed, are no exception. The bronze doors of the period had not only a practical meaning, but were also a visual expression of narrative, thus carrying out an educational mission and being a shaper of society's approach to certain things. One can distinguish two methods in the depiction of the analysed mythical creatures in bronze doors. In some places, the centaurs do not differ very much in size, and are depicted only among the supplementary decorative elements, without giving them special attention (the bronze doors of the 12th-century Trani and Gniezno cathedrals). Elsewhere, centaurs are distinguished by their size and place in the door. In this case, the centaurs are depicted not in the curb of the door among the decorative elements, but in the panels of the door. In this way, their figures 'participate' with all rights in the story created and depicted in the bronze door, or just express a certain meaning of the symbol (the bronze doors of the

${ }^{38}$ R. Petrauskas, 'Riterystès plitimas Lietuvos bajorų visuomenèje', Lietuvos istorija, t. IV: Nauji horizontai: dinastija, visuomene, valstybe. Lietuvos Didžioji Kunigaikštysté 1386-1529 m. (Vilnius, 2009), p. 234; idem., 'Riteriai Lietuvos Didžiojoje Kunigaikštysteje XIV a. pabaigoje-XVI a. pradžioje', Istorijos šaltiniu tyrimai (Vilnius, 2008), pp. 91-113.

${ }^{39}$ G. Małaczyńska, 'Szymon (Semen) Hołszański', Polski Słownik Biograficzny (Wrocław, 1960), t. IX/4, z. 43, p. 590. 
11th-century Augsburg Cathedral," and the 12th-century Novgorod Sophia Cathedral, also known as the Magdeburg Gates). A religious scene was characteristic of the door panels in the bronze doors of medieval churches. They reflect scenes from the Old and the New Testament: the creation of Adam and Eve and their expulsion from Paradise, the crucifixion of Jesus, lives of the Apostles, and so on.

Bronze doors decorate the western portal of the Sophia Cathedral in Novgorod, one of the few examples of Romanesque sculpture in this region. These doors were produced in 12th-century Magdeburg. It is believed that in the second quarter of the 14th century they were brought to Orthodox Novgorod ${ }^{40}$. Attention is drawn to the fact that the centaur depicted in the western bronze doors of the Sophia Cathedral of Novgorod differs in particular from the stories depicted in the other door panels. In all the stories depicted on the door panels, more than one player participates, thus completely filling up the fields of the panel. The centaur in this respect is very different, as he is depicted alone in the panel alone, shooting an arrow, and his figure in the rest of the blank field immediately attracts attention. One has to add that this panel with the centaur is in the worst place of the bronze door, in the bottom corner, and if we also look at its location from a heraldic point of view, he is portrayed on the inferior heraldic left ${ }^{41}$. This negative value of the centaur is also reinforced by the fact that in the parallel lower-level part of the left door the story of the creation of Eve and the tasting of the forbidden fruit is depicted. From that, one can see that a rather ambiguous meaning is assigned to the centaur. On one hand, an extremely negative attitude to him is shown, but, on the other hand, the centaur is depicted so that he can easily draw the attention of all, thus giving him an extraordinary position. Aleksandr Veselovskii states that perhaps some of the apocryphal stories about Solomon and the hippocentaur can be related to the Bulgarian and Greek Bogomils. In 1123, arriving in Russia heretics Adrian and Dmitry belonged

\footnotetext{
${ }^{40}$ A.N. Trifonova, 'Bronzovye dveri Sofiiskogo sobora v Novgorode', Novgorod i Novgorodskaia zemlia. Istoriia i arkheologiia. Materialy nauchnoi konferentsii, No. 9/95 [interaktyvus] [address visited on 21 Jan 2010]. Access through internet: $<$ http://bibliotekar.ru/rusNovgorod/37.htm>; Magdeburgskie vrata Sofiiskogo sobora, Russkaia istoriia i kul'tura. Srednevekovaia Rus'. Velikii Novgorod. Istoriia Velikogo Novgoroda [interaktyvus] [address visited on 21 Jan 2010]. Access through internet: <http://bibliotekar.ru/novgorod/58.htm>.

${ }^{41}$ Based on consultations with doc. dr E. Rimša.
} 
to the Bogomil sect ${ }^{42}$. It can be assumed that namely they could have spread in Russia the apocryphal story about Solomon and the Hippocentaur-Centaur. From the 14th century stories about Solomon and the Hippocentaur (Talmud legends described the equivalent of Solomon's opponent Asmodeus) are fixed in the legends described in ancient Russian books ${ }^{43}$. It is possible that the Orthodox Alšèniškis dukes may also have been familiar with these stories. According to R. Bagdasarov, in the 14th and 15th centuries in Novgorod, the depiction of a centaur in Church art was extremely popular ${ }^{44}$. The Lithuanian princes had formed strong ties with Novgorod. Simonas Lengvenis, later Aleksandras Čartoriskis, Mykolas Olelkaitis and other dukes, ruled Novgorod. From the Alšèniškis family, the most closely tied to Novgorod were Simonas and Jurgis Simonaitis Alšèniškis ${ }^{45}$. For these reasons, the arrival from Novgorod of the centaur in the heraldry of the Alšèniškis and later of other nobles of the GDL is very likely.

\section{The Centaur's transformation into the Hippocentaur}

On the seals of Andrius Simonaitis and Simonas Jurgaitis Alšėniškis (the middle of the 15 th century and 1490 respectively) ${ }^{46}$, one can see the results of the transformation of the Centaur to the Hippocentaur. In these seals, mythical figures in the upper (a man to the waist) part is shooting an arrow into the lower part of his body, a steed's tail, turned into a grass-snake. This composition of the coat of arms symbol, even in later centuries, essentially did not change any more. What determined this change in the heraldry of the Alšèniškis dukes? Jan Jurkiewicz argues that the change might be associated with the Alšėniškis' contact with Western culture, where the centaur was a popular character both in literature and art. The researcher draws attention to astrological maps in which Sagittarius was depicted with a bow and arrow, sometimes turned towards his

42 A. Veselovskii, Merlin i Solomon. Slavianskie skazaniia o Solomone i Kitovrase i zapadnye legendy o Morol'fe i Merline (Moscow, 2001), pp. 180, 184.

${ }^{43}$ A.G. Silaev, 'Kitovras', Russkaia geraldika [interactive] [address visited on 21 Jan 2010]. Access through the internet: <http://silaev-ag.ru/dict/138>.

44 R. Bagdasarov, 'Symbolics of the Constellations', p. 991.

${ }^{45}$ K. Krupa, 'Polityczne związki Giedyminowiczów z Nowogrodem Wielkim w latach 1430-1471', Przeglad Historyczny, 84 (1993), pp. 302-303.

46 O. Odnorozhenko, Kniazivs'ka, p. 171. 
tail. This composition of the archer, according to Jan Jurkiewicz, might have inspired the Alšeniškis dukes to correct their heraldry ${ }^{47}$. Without rejecting the influences of Western culture on Alšèniškis heraldry, nevertheless, the question remains, why did the centaur's tail turn into a grass snake? One can assume that the correction of the coat of arms was inspired by the establishment and spread of Christianity. Sofia Alšèniške, the fourth wife of Jogaila, was an active financial patron of Christianity. The Alšeniškis were Orthodox from the second half of the 14th century ${ }^{48}$. Consequently, the Christian tradition of the princely tribe had to be strong. With this in mind, one can assume that the Alšeniškis dukes assigned themselves one more 'battle' function. In the early Christian period, the grass-snake embodied the spring of goodnesss, in the Middle Ages it was demonised. Its symbolism became associated with the spirit of darkness and hell, a demon, the spring of evil ${ }^{49}$. In this way, the Hippocentaur composition in the Alšeniškis coat of arms, in which the grass-snake is targeted, expresses two aspects characterising fights. First of all, it is the struggle of a man with his animal instincts, with his sinful, easily tempted, nature. Bearing in mind that the grass-snake is one of the symbols of paganism, the coat of arms could have manifested the fight between Christianity and paganism. It can be assumed that for the Alšèniškis dukes, the latter aspect was perhaps the most important in the choice of a composition with a Hippocentaur in their coat of arms. This point would be particularly important if, after further investigation, it turned out that the transformation of the Centaur to the Hippocentaur occurred at the time when the Alšèniškis became Catholics.

\section{The Hippocentaur in the heraldry of the Giedraitis (Giedroyć) family reminiscences of the Renaissance epoch}

Although, as was already discussed in the introduction, in addition to the Alšenniškis dukes, other families of the Grand Duchy of Lithuania had the Hippocentaur coat of arms, in this work we will analyse further only the heraldry of the Giedraitis family. This fam-

47 Jurkiewicz, 'Palemon', p. 141.

${ }^{48}$ E. Gudavičius, 'Alšėnų kunigaikščiai, Alšèniškiai', Visuotine lietuvių enciklopedija, t. 1 (Vilnius, 2001), p. 390.

${ }^{49}$ P. Dundulienè, Žaltys ir jo simboliai lietuvių liaudies mene ir žodinèje kūryboje (Vilnius, 2005), pp. 122-123. 
ily of nobles was chosen on purpose, because Giedraitis heraldry is in part quite closely related to the already discussed Alšenniškis. Nevertheless, the reason why the Giedraitis chose to use the Hippocentaur coat of arms is completely different, but also dictated by the realities that existed in the society of the Grand Duchy of Lithuania at that time.

There are three known coats of arms used by the Giedraitis (in chronological order): Rose, Hippocentaur, and a Hippocentaur composition with a Rose. The Hippocentaur coat of arms appears in Giedraitis sfragistics only in 1565, i.e. in the seal of Mikalojus Giedraitis. ${ }^{50}$ Mikalojus Giedraitis in a 19th century document, the confirmation of the nobility of the Giedraitis family, is identified as the founder of the family line which used the Hippocentaur and Rose coat of arms. ${ }^{51}$ There are no earlier written sources testifying to the use of the Hippocentaur coat of arms, because until the middle of the 16th century the Rose coat of arms is in the Giedraitis seal. One could present as examples the $1544,{ }^{52} 1548^{53}$ and $1556^{54}$ documents found, respectively, in the signet seals of Motiejus Giedraitis, Baltramiejus Giedraitis and Kristupas Giedraitis, with the Rose coat of arms.

In the middle of the 16th century, the Roman theory was already well established in the society of the Grand Duchy of Lithuania. According to this theory, as has already been mentioned, the Giedraitis and Alšeniškis families were descended from the same family, the brothers Giedrys and Alšys. In 1555, after the death of the Bishop of Vilnius Paulius Alšèniškis, the last male member of the Alšèniškis family, a famous family of the Grand Duchy of Lithuania, which used the Hippocentaur coat of arms, the line was extinguished. In this way, it is possible to assume that the opportunity arose for the Giedraitis to pick up the used Hippocentaur coat of arms and start to use it in their heraldry. One should bear in mind that the Hippocentaur was not a totally foreign coat of arms to the Giedraitis. Like the family coat of arms of the Alšeniškis, it was somehow validated in the Lithuanian Chronicles, based on the common Roman origin

${ }^{50}$ Based on consultations with doc. dr E. Rimša.

${ }^{51}$ Wywod Familij Urodzonych Giedroyciow, Herbu Hipocentaurus z Różą, 1830, LVIA, f. 391, ap. 1, b. 605.1, 1. 141 (96v).

52 Seal of Motiejus Giedraitis in 1544, LMAVB RS, F 273-4017.

53 Seal of Baltramiejus Giedraitis in 1548, ibid., F 273-2241.

${ }^{54}$ Seal of Kristupas Giedraitis in 1556, ibid., F 12-3846. 
of these dukes. Since the theory "of this origin was widespread in society, it could be treated just as the return to a previous coat of arms, and not as the appropriation of another. The extinction of the Alšèniškis could only facilitate this situation.

Basically, both the Rose and the Centaur/Hippocentaur are coats of arms symbolising the legendary Roman origins, mentioned in the Lithuanian Chronicles. The priority given to the Centaur is probably related to the fact that it was the legendary coat of arms of the ruling dynasty. At the end of the 16th century the Giedraitis dukes used both of these coats of arms. For example, in the coat of arms of Grigalius Giedraitis, already in 1580, there is both a Rose and a Hippocentaur ${ }^{55}$. In the late 17 th century to the 19th century, the number of Giedraitis using the Rose as their coat of arms is relatively small $^{56}$. These Giedraičiai could not boast of representatives with senior duties or a princely origin in general. The Giedraitis Pukieniai and the Giedraitis Juraha branches used the Hippocentaur coat of $\operatorname{arms}^{57}$. From the nobility confirmation documents of the mentioned members of the branches, one can see that the Giedraitis Pukieniai claimed descent from the line of the Giedraitis family that had the title of dukes ${ }^{58}$. Relying on Józef Wolff, one can also affirm that the Giedraitis Juraha were also a ducal branch of the Giedraitis ${ }^{59}$. In this way, the Hippocentaur is associated with the Giedraitis family claiming descent from the princely branches of the Giedraitis, and the Rose with junior members of this family. There is a good chance that the not-so-famous members of the Giedraitis family began to use the Hippocentaur coat of arms in order to improve

55 Seal of Grigalius Giedraitis in 1580, LVIA, f. 1178, ap. 1, b. 296, 1. 3. For this reference I sincerely thank doc. dr E. Rimša.

${ }^{56}$ Wypis Ksiąg Schlacheckich Gubernij Litewsko Wilenskieij Wywodu Familij Urodzonych Giedroyciow, Herbu Poray, 1801, LVIA, f. 708, ap. 2, b. 5.

57 Wywod Familii Urodzonych Xiążątt Giedroyciow, Herbu Hipocentaurus, 1810, ibid, f. 391, ap. 1, b. 992.4; Wywod Familij Urodzonych Giedroyciow, Herbu Hipocentaurus, 1819 m., ibid, f. 391, ap. 1, b. 334; Wypis Ksiąg Schlacheckich Gubernii Littewsko-Wileńskieij Wywodu Familii Urodzonych Pukieniow Giedroyciow, Herbu Hipocentaurus, 1819 m., ibid., f. 708, ap. 2, b. 1; Wywod Familij Urodzonych Giedroyciow, Herbu Hipocentaurus. 1820 m., ibid., f. 391, ap. 1, b. 1002; Rough Copy of Giedraitis Family Tree in 1822, VUB RS, F5-A40-7888.

${ }^{58}$ Wywod Familij..., 1820, LVIA, f. 391, ap. 1, b. 1002, 1. 200; Wypis Ksiąg..., 1819 m., ibid., f. 708, ap. 2, b. 1, 1. 298.

59 J. Wolff, Kniaziowie litewsko-ruscy od końca czternastego wieku (Warsaw, 1895), p. 76. 
their status in society. Starting to use the Hippocentaur coat of arms could have become, if not the main, a sufficiently important, factor to achieve this goal.

\section{Conclusions}

The Centaur as a coat of arms has two semantic meanings. One of them is the legendary Centaur that existed in the minds of the nobility of the GDL, developed, already fixed in the Lithuanian Chronicles as an expression of the ancestors of the famous princely families of the GDL from Rome, an expression of their adored ancient origin. On the other hand, this coat of arms performed a real function: it was the hallmark of noble people, expressing the personal aspirations of its holders.

One can assume that the Centaur came to the heraldry of the nobles of the GDL, and first of all the Alšeniškis, through the Church (through Church art and literature). Both the Church of the East and of the West, in the symbolism of which this mythical creature was very popular, could have influenced the selection by the Alšèniškis of the Centaur symbol in their coat of arms. An analysis of available sources and scholarly literature allows us to regard Novgorod as one of the possible paths for the appearance of the Centaur through the Church of the West and the East. The reason for the selection of the Centaur could have been linked to warfare, to the political situation arising in the GDL at that time. The sequence of these facts shows the change in the sfragistics/heraldry of the Alšeniškis dukes: in the 1390 seal of Jonas Alšeniškis is the figure of St John; in 1420 Simonas Jonaitis Alšèniškis, the son of Jonas Alšèniškis, on the instructions of Vytautas, travels to Novgorod; while in 1422/1423 in the seals of Simonas Jonaitis Alšèniškis and Mykolas Jonaitis Alšeniškis attached to the Treaty of Melno there is a Centaur. Eventually, as Christianity and contacts with Western culture increasingly strengthened in the country, the Centaur during the second quarter of the 15th century transformed into a Hippocentaur. The function of the Alšèniškis coat of arms, i.e. what was desired to be said by the coat of arms, was expanded. The Hippocentaur could also be a symbol of Christianity, as the opposite of paganism.

The appearance of the Hippocentaur coat of arms in the heraldry of the Giedraitis in the second half of the 16th century is linked with the disseminated Renaissance ideas, the entrenchment of the 
myth of Roman origin in the world-view of the nobility, and in the awareness its own identity, as well as the extinction of the Alšeniškis dukes. Because the Giedraitis with a lower status in society than other members of their family began to use the Hippocentaur coat of arms in their heraldry, it is conjectured that in this way they wanted to emphasise their nobility and the old age of their family. From the end of the 16th century in Giedraitis heraldry, the coats of arms of the Rose and Centaur/Hippocentaur were used, but in some family lines the Hippocentaur eventually began to dominate.

Author Details

Agnè Railaitė-Bardè is a doctoral student at Vilnius University, the Faculty of History, in the Department of Ancient and Medieval History, and senior assistant in the Lithuanian Institute of History's Department of the History of the Grand Duchy of Lithuania. Major academic interests: the heraldry and genealogy of the Nobles of the Grand Duchy of Lithuania.

Address: Lithuanian Institute of History, Kražių g. 5, LT-01108 Vilnius

Email: agnerailaite@gmail.com

\section{HIPOCENTAURO ATSIRADIMAS LIETUVOS DIDŽIOSIOS KUNIGAIKŠTYSTĖS KILMINGŲJŲ HERALDIKOJE}

Santrauka

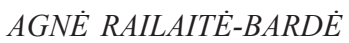

Kentauras arba Hipocentauras Lietuvos Didžiosios Kunigaikštystės kilmingųjų heraldikoje yra beveik netyrinètas. Ši tema - dar neišsemtas heraldikos tyrimų aruodas, dèl pirminių šaltinių stokos sukeliantis mokslininkams daugiau klausimų nei atsakymų. Klausimas, iš kur ir kokiu būdu LDK kilmingujjų heraldikoje atsirado Kentauras, vėliau virtęs Hipocentauru, istoriografijoje tebėra balta dèmé. Šiame straipsnyje aptariama kentaurų istorija ir simbolika, analizuojama Lietuvos metraščiuose aprašoma Kentauro gimine, tiriamos Alšèniškių herbo pasirinkimo, Kentauro virsmo Hipocentauru bei Hipocentauro herbo atsiradimo Giedraičiu heraldikoje XVI a. prielaidos, tikslinamos Kentauro, Hipocentauro, Kitauro ir Šaulio (Sagittariaus) sąvokos. Straipsnyje daroma prielaida, jog Kentauras ị LDK kilmingųjų, o pirmiausia ị kunigaikščių Alšèniškių heraldiką, atejjo per Bažnyčią (per bažnytinị meną ir literatūrą). Alšèniškių Kentauro simbolio savo herbe pasirinkimą galèjo lemti tiek Rytų, tiek Vakarų Bažnyčia, kurios simbolikoje ši mitinè būtybẻ buvo labai populiari. Turimų šaltinių ir mokslinès literatūros analizė leidžia Naugardą laikyti vienu iš galimų Kentauro atsiradimo per Vakarų ir Rytų Bažnyčią kelių. Kentauro pasirinkimo motyvas galèjo būti susijęs su karyba, tuo metu LDK susidariusia politine situacija. Kunigaikščių Alšėniškių sfragistikos/heraldikos kaitą nurodo šių faktų seka: 1390 m. Jono Alšèniškio antspaudo vaizdulyje yra šv. Jono 
figūra, 1420 m. Jono Alšèniškio sūnus Simonas Jonaitis Alšèniškis Vytauto pavedimu vyksta ị Naugardą, o jau 1422/1423 m. Simono Jonaičio Alšèniškio ir Mykolo Jonaičio Alšèniškių prie Melno taikos prikabintų antspaudų vaizduliuose yra Kentauras. Ilgainiui, šalyje vis labiau stiprejjant krikščionybei ir kontaktams su Vakarų kultūra, Kentauras per XV a. antraji ketvirtị virto Hipocentauru. Alšèniškių herbo funkcija, t.y. tai, ką buvo norima tuo herbu pasakyti, buvo išplèsta. Hipocentauras galèjo būti ir krikščionybès, kaip priešpriešos pagonybei, simbolis. Hipocentauro herbo atsiradimas Giedraičių heraldikoje XVI a. II puseje siejamas su Renesanso skleidžiamomis idejjomis, romėniškojo kilmès mito ịsitvirtinimu kilmingujjų pasaulèžiūroje ir savo tapatumo savivokoje bei kunigaikščių Alšèniškių išmirimu. Kadangi Hipocentauro herbą savo heraldikoje pradèjo naudoti visuomenèje žemesnị statusą už kitus savo giminès atstovus turintys Giedraičiai, spèjama, kad tokiu būdu jie norejo pabrēžti savo kilmingumą ir giminès senumą, kas buvo labai svarbu XVI a. 